\title{
HO CHI MINH'S THOUGHT ON MASS MOBILIZATION AND THE APPLICATION OF THIS VIEW BY THE COMMUNIST PARTY OF VIETNAM IN CURRENT SITUATION
}

\author{
Ngoc Loi Pham \\ Faculty of Public Relations and Social Work \\ Ho Chi Minh City Cadre Academy \\ Ho Chi Minh City, Vietnam \\ E-mail: huyenhong83@gmail.com
}

\begin{abstract}
Over half a century ago, President Ho Chi Minh gave a basic thought about the mobilization work of a revolutionary Party in a famous article published in the newspaper "The Truth" (Su That). That work is considered as the platform for the work of mass mobilization. His thoughts have led our Party to implement the mobilization work to achieve great achievements, decisive to the victory of our revolution during the past 71 years. This study aims to analyze President Ho Chi Minh's thoughts on mass mobilization. The author used scientific research methods such as analysis and synthesis, interpretation and induction, abstraction and generalization, logic and history, and comparison to come to conclusions and general judgment. The study focused on clarifying the contents of Ho Chi Minh's Thoughts on mass mobilization and the application of the Communist Party of Vietnam in current conditions.
\end{abstract}

Keywords: Ho Chi Minh's Thought, The Communist Party of Vietnam, Mass Mobilization.

\section{INTRODUCTION}

Ho Chi Minh's ideology on mass mobilization is a component of his system of thoughts on the Vietnamese revolution. This view is clearly expressed in Ho Chi Minh's work "Mass mobilization" written seven decades ago. But the contents of the work in which the central idea is "taking people as the root" still maintain theoretical and practical values, illuminating the innovation cause in Vietnam. President Ho Chi Minh was a genius and beloved leader of Vietnam, a prominent communist soldier of the communist and international worker movement. His legacy and thoughts left to the whole Party and our people are big and precious, including the work of "Mass Mobilization". This work was written 71 years ago on October 15, 1949, and published in the newspaper "The Truth", Vol. 120 by the penname X.Y.Z. In only 619 words, the work conveyed the contents and messages expressing the great ideology of the leader who devoted wholeheartedly to the country and people. The work of "Mass Mobilization" includes four main contents: i) Our country is a democratic nation; ii) What is mass mobilization? iii) Who is in charge of mass mobilization? iv) How is mass mobilization? Especially, the idea of "taking the people as the root" is the focal point of the work.

\section{LITERATURE REVIEW}

Traditionally, in the history of wars and revolutions of humans, the ruling classes, forces, and political parties have been concerned with the gathering of mass forces to support them. In the history of building and defending our country, the feudal class in many dynasties respected the 
idea of "taking the people as the root" and knew how to mobilize the people to gain domination and fight against foreign invaders to protect the country. Tran Quoc Tuan, the national hero, the eminent representative of the Tran dynasty mandarin, stated: "The will of the people is the strongest fortress to safeguard the country, and promoting the people's strength is the top policy of the country" (Do, 2019). Nguyen Trai, the eminent strategist of the Lam Son insurgent army, also said: "it is the power of the people that carries the boats". "It needs to be very harmonious in the relations with the people. The worries of the people are the worries of the century" (Mai, 2018). However, due to the limited conditions of history and the class stance, the feudal groups did not form a basic, consistent, and complete policy for the mobilization work.

Ho Chi Minh absorbed the minds of the people in the history of the nation to evaluate the position, role, and strength of the people. For example, he inherited Tran Quoc Tuan's point of view in the work Van Kiep Esoteric Book, "The benefits of the people are the top policy to defend the nation". Besides, he learned from Phan Boi Chau who affirmed that the people were the masters of a country, not the king, and there was a close relationship between the people and nation. He wrote, "my people belong to my country. The people are the country's people and the country belongs to the people" (Thanh, 2020). Ho Chi Minh also absorbed the theory of Marxism-Leninism that "Revolution is the cause of the masses", and "the people are the creator of history".

Based on absorbing the national tradition and the theory of Marxism-Leninism, Ho Chi Minh highly valued the role of the people. He affirmed, "People are the root of the country", and the people are the main force of the revolutions; "All forces lie in the people's place", "The power of the people is strong" (City, 2011a). The thought of promoting the people for the benefit of the people is the ideal, the goal, the life motto, and the revolutionary operation method of President Ho Chi Minh. That great thought is expressed by Ho Chi Minh's work of Mass Mobilization (Dan Van).

Thus, absorbing and developing the progressive thought of humanity and the nation, from the lessons of success and failure of the world revolution and the Vietnamese revolution, notably from the practical experience of leadership of Vietnam revolution from 1930 to 1949, President Ho Chi Minh, with his strategic vision, summarized and raised the critical issues of the mobilization work.

\section{HO CHI MINH'S THOUGHT ON MASS MOBILIZATION}

The power of the people is big, which is the decisive factor for all victories. It is a simple thing that everyone understands. But, what is the issue of mass mobilization? Why is it so important? Who is in charge of mass mobilization? All of the above questions have not been answered seriously. It is the first time in the history of our nation's thoughts, President Ho Chi Minh's work on mass mobilization has basically and concretely answered those questions.

The concept of mass mobilization given by President Ho Chi Minh was highly generalized with authentic and rich content. The work of Mass mobilization became the classics of Marxism-Leninism about mass mobilization.

The work of mass mobilization is humanistic, in which all benefits deriving from the people. At the beginning of the work, President Ho Chi Minh affirmed the main thesis, "Our country is a democratic country" (City, 2011a). It can be seen that democracy is the theoretical basis and the key to the mass mobilization work. The people are the "root" of the country and the subject of all historical creative activities (Van, 2020). 
The people are the masters of the country, so "all interests and powers belong to the people and for the people" (City, 2011a). The government must consider the interests of the people as a goal, and all powers, policies, and laws must be for the benefit of the people, serving the people (Son, 2019). Also, the Party and Government should not have any other interests. Ho Chi Minh stated, "the people are the masters, so the government is a server. Becoming officials today is not for promotion and fortune" (City, 2011b).

The nature of our nation is a democratic state that is "the people are the masters of the country". They are entitled to all democratic rights including the right to live, the right to have freedom, and the right to work according to their abilities to the extent permitted by law. The State must protect its people's ownership by building and perfecting democratic institutions so that they can be true masters in all economic, political, cultural, and social fields. Ho Chi Minh emphasized the highest status of the people because they are masters of the country (Phuc, 2020). All power belongs to the people, all benefits are for the people, and all work is done by the people.

Therefore, the people enjoy the rights of ownership, and at the same time, have the obligations and responsibilities of the owner. "Renovation, construction are the responsibilities of the people. The cause of the resistance war and national construction is the work of the people" (City, 2011a). The people have the responsibility to build and manage their country, "The government from the commune to the central is elected by the people" (City, 2011a). Mass organizations from central to local are organized by the people. Each citizen must be obliged to fulfill its civic duty and to keep civic morality to exercise his democratic rights.

President Ho Chi Minh's affirmation that 'all power and force belong to the people" stated in his work Mass mobilization (Dan Van) is the starting point, as well as the guiding motto for all activities and work of our Party and Government. The Party, State organizations, each official, and party member must grasp and deeply understand the role of the people, thereby training awareness and responsibility to well fulfill the tasks assigned by the people. They should have a close relationship with the people, learn from the people, and understand the people's feelings and aspirations to work for the prosperous and happy life of the people. In other words, it is necessary to well mobilize, gather, and promote the strength of the entire people to serve them well.

Stemming from explaining the nature of the State, in his work Mass mobilization, President Ho Chi Minh has gradually clarified many problems in the mobilization of the masses, both in content and implementation methods. All issues that "Our country is a democratic country"; "What is mass mobilization?", "Who is in charge of mass mobilization work?", "How should mass mobilization be?" has clearly shown the relationship between the objective, the task, and the solution.

To bring a life of freedom, prosperity, and happiness to all people through the building of a democratic state, the real state of the people, by the people, for the people, in the work of Dan Van, President Ho Chi Minh pointed out one of the basic tasks is to unite, gather forces, and build a great national unity bloc. He stated, "Mobilizing all forces of each person, not leaving a single person behind, contributing to the entire population force" (City, 2011a). It is also the content of the mass mobilization work, which explains the concept of mass mobilization.

To perform well the mobilization work, according to Ho Chi Minh, it is necessary to synchronously implement many solutions, especially respecting the principle of "taking the people as the root." 
First of all, it is necessary to clarify: Who is in charge of mass mobilization work? According to Ho Chi Minh, mass mobilization is to mobilize all the people, so that is the responsibility of the whole political system: "The unions and all members of mass organizations (Lien Viet, Viet Minh, etc.) must be in charge of mass mobilization” (City, 2011a).

Regarding methods of implementation, according to Ho Chi Minh, there must be a combination of propaganda, explanation, and actions. In which, propaganda and explanation are the first steps for "each citizen to understand clearly: It is for their benefits and their duties, so they must eagerly make the work possible (City, 2011a). At the same time, it is essential to discuss with the people, "consult with the people and make practical plans with the local circumstances, then encourage and organize the entire population to implement them" (City, 2011a). Cadres in charge of mass mobilization must "follow, help, urge and encourage the people" (City, 2011a), "show the people how to do it". There must be summaries, "to learn from experience, criticize, and reward" to promote the movement. In particular, President Ho Chi Minh asked cadres in charge of mass mobilization to "talk along with actions", to "honestly put their hands on things", "do not speak plainly", "just sit and write orders" (City, 2011a); they must "be a model for the people" (City, 2011a).

The idea of "taking the people as the root" is a typical feature of the whole work Mass mobilization. Therefore, President Ho Chi Minh always asked each official and party member to "be close to the people" and to have a good relationship with the people (VNA, 2020). For cadres in charge of mobilization, that requirement became even more necessary. Mobilization officers must have the manner: "thinking, looking, hearing, walking, speaking, doing" (City, 2011a), only on that basis, can they be close to the people, and understand the people, thereby mobilizing them to participate in the revolutionary cause. It is a lesson that everything must come from the interests of the people, and cadres must be close to the people. In the work of "Mass mobilization", President Ho Chi Minh outlined the content and implementation method for mobilization. At the same time, he also pointed out and criticized the limitations when many officials "look down on the work of mass mobilization" (City, 2011a), surrendered this work to others, irresponsibly, "considers themselves not to be responsible for mobilization." It is not only a defect but also a grave mistake (City, 2011a). This instruction of President Ho Chi Minh is of great significance, which is a valuable lesson for all cadres, party members, and political apparatus of the Party and State since the power of the people is very strong. "Mass mobilization is important. Bad mass mobilization will lead to bad results; good mass mobilization will result in success" (City, 2011a).

\section{THE COMMUNIST PARTY OF VIETNAM'S APPLICATION OF HO CHI MINH'S THOUGHT ON MASS MOBILIZATION IN THE PRESENT TIME}

The cause of national renewal in Vietnam (1986) was derived from the wishes, "aspirations and initiatives of the people" and responded by the people to achieve today's achievements. Therefore, the National Construction Platform in the transition period to socialism (amended in 2011) affirms: "The cause of the revolution is of the people, by the people, and for the people. It is the people who make the historic victories. All activities of the Party must come from the legitimate interests and aspirations of the people. The Party's strength lies in its close relationship with the people. Bureaucracy, corruption, and alienation from the people will lead to immeasurable losses to the destiny of the country, the socialist regime, and the Party (The Communist Party of Vietnam, 2011). Summarizing 30 years of renovation, the Communist Party of Vietnam continues to affirm the role of the people: "Innovation must always grasp the 
viewpoint considering the people as the base, for the sake of the people, based on the people to promote the role of the people as the masters of the nation, their sense of responsibility, creativity, and all resources, and to promote the strength of national solidarity (The Communist Party of Vietnam, 2015).

Relying on the people to build a clean and powerful Party and State to serve the people better is always a consistent viewpoint in the Party's undertakings and lines and the State's policies and laws. The Communist Party of Vietnam has issued many directives and resolutions to consistently express the above point of view, typically Resolution No. 08B-NQ / TW (term VI), dated March 27, 1990 on reforming mass mobilization, strengthening the relationship between the Party and people; Directive No. 30-CT / TW, dated February 18, 1998 of the Politburo (term VIII) on the formulation and implementation of the democratic regulations at grassroots level; Resolution No. 25-NQ / TW, dated June 3, 2013 on strengthening and renewing the Party's leadership towards mobilization work in the new situation (Session XI); Decision No. 217-QD / TW, Decision No. 218-QD / TW of the Politburo (Session XI), dated 12/12/2013, on "promulgating regulations on social monitoring and criticism of the Vietnam Fatherland Front and socio-political organizations ","Promulgating regulations on the Vietnam Fatherland Front, socio-political organizations and people participate in building the Party, building the main permission"; Conclusion No. 120-KL / TW, dated January 7, 2016 of the Politburo (Session XII) on "continuing to promote and improve the quality and effectiveness of the development and implementation of the Grassroots Democracy Regulation. These are very specific and valuable regulations and instructions on the contents, subjects, methods of monitoring, social criticism, and contributing opinions of the Vietnam Fatherland Front, socio-political organizations - and the people towards the Party and State. Since then, the entire political system and each agency, unit, officer, and party member have the basis to promote to the highest level of the people's power in new historical conditions. Relations with the people are also constituted in the Constitution and laws of the State. The Constitution, it affirms: "The Communist Party of Vietnam is closely attached to the People, serves the people, is subject to the supervision of the people, and is accountable to the people for its decisions" (The 2013 Constitution of the Socialist Republic of Vietnam).

In the current period, when the world and domestic situation are constantly changing, the hostile forces are seeking to destroy the revolutionary cause of the Party and the people of Vietnam. The Party must gain people's trust because it is the biggest asset of the ruling Communist Party of Vietnam. However, in reality, the people's trust in the Party has declined in some places, which has a bad influence on the renovation of our country.

\section{CONCLUSION}

In summary, Ho Chi Minh's thought on mass mobilization is considered the platform which has led our Party to implement the mobilization work to gain great achievements. The Communist Party of Vietnam should apply the viewpoint "Taking the people as the root" - the precious value of Ho Chi Minh's thought in the work Mass Mobilization into the new situation. All activities, undertakings, and policies of the Party and the laws of the State must come from the aspirations and the will of the people, performed by the people, and aim to bring benefits to the people. Gaining the people's trust should be one of the objectives of the leadership of the Party. Especially, the Party must keep a close relationship with the people. The people are also the resource and strength to build a clean and strong Party and State, so it is necessary to promote the strength of the people in the work of building the Party and State. 


\section{REFERENCES}

City, H. C. M. (2011a). Complete Works, Volume 6, Hanoi: National Political Publishing House

City, H. C. M. (2011b). Complete Works, Volume 5, Hanoi: National Political Publishing House

Do, T. K. (2019). Some things about "reducing the contribution of the people". Retrieved from https://nhandan.com.vn/chinh-tri-hangthang/doi-dieu-ve-khoan-thu-suc-dan-348778/

Mai, H. H. (2018). The thought of the great national unity in the Lam Son uprising lasts forever. Retrieved from: https://vanhoadoisong.vn/web/trang-chu/xa-hoi/sang-mai-tu-tuong-daidoan-ket-dan-toc-trong-cuoc-khoi-nghia-lam-son.html

Phuc, N. T. (2020). Ho Chi Minh Thought about the State of the people, by the people, and for the people. Retrieved from https://tcnn.vn/news/detail/48155/Tu-tuong-Ho-Chi-Minh-veNha-nuoc-cua-nhan-dan-do-nhan-dan-va-vi-nhan-dan.html

Son, D. (2019). All state power belongs to the people. Retrieved from http://tuyengiao.vn/nghien-cuu/de-tat-ca-quyen-luc-nha-nuoc-thuoc-ve-nhan-dan-119076

Thanh, P. D. (2020). Discussing the Constitution. Retrieved from http://quochoi.vn/tulieuquochoi/anpham/Pages/anpham.aspx?AnPhamItemID=29

The Communist Party of Vietnam. (2011). The Platform for Country Building in Transition to Socialism (revised in 2011). Hanoi: National Political Publishing House.

The Communist Party of Vietnam. (2015). Central Executive Committee, Steering Committee summarize: Report summarizing some theoretical and practical issues over 30 years of reform (1986 -2016). Hanoi: National Political Publishing House.

The 2013 Constitution of the Socialist Republic of Vietnam. Retrieved from https://vietnamlawmagazine.vn/the-2013-constitution-of-the-socialist-republic-ofvietnam-4847.html

VNA. (2020). Building Party Committee in close relationship with the people. Retrieved from http://tapchithongtindoingoai.vn/ly-luan-thuc-tien-kinh-nghiem/xay-dung-dang-bo-ganbo-mat-thiet-voi-nhan-dan-36057

Van, B. (2020). A precious lesson, considering the people as the base. Retrieved from http://noichinh.vn/nghien-cuu-trao-doi/202002/bai-hoc-quy-lay-dan-lam-goc-307515/

\section{Copyrights}

Copyright for this article is retained by the author(s), with first publication rights granted to the journal. This is an open-access article distributed under the terms and conditions of the Creative Commons Attribution license (http://creativecommons.org/licenses/by/4.0/) 